\title{
COMPETITIVE FACTORS IN ENSURING THE SUSTAINABILITY OF THE FOOD INDUSTRY ECONOMY
}

\section{Ismailov Omilxon Shukurillaevich}

Dean of the Uzbek-Belarusian joint faculty of innovative pedagogy of Tashkent State Pedagogical University named after Nizami factorxon.i@mail.ru

\begin{abstract}
This article discusses the issues of competition in ensuring the sustainability of the food industry in the world economy, the sources and stages of competitive advantages of States. The role of natural resources, investments and other elements in increasing the economic competitiveness of the state, as well as the stages of competitiveness of developed countries are discussed.

Keywords: World Economy, Food Industry, Investment, M. Porter, UK, USA, China, Singapore, Agriculture, A.Yu. Husanov, Ramensky.

Article Received: 18 October 2020, Revised: 3 November 2020, Accepted: 24 December 2020
\end{abstract}

In the current conditions of development of the world economy, a necessary condition for the equal participation of the state in international cooperation is the competitiveness of the national economy, in this regard, the study of the problem of competitiveness is especially relevant. Accordingly, in order to address the problem of food industry development at all levels of the economy, it is necessary to take into account the impact of all stages of competitive relations. At the same time, each level of the competitive environment has its own factors, evaluation methods and strategies to achieve competitiveness. Depending on the level of the economy, the competitive advantages of the country, industry and enterprise are distinguished.

Therefore, the competitive advantage of the state is determined by the stage of its competitiveness, according to which the following sources of competitive advantage are distinguished: factors of production, investment, innovation and the accumulated wealth of the country.

At the factor stage, a country's competitive advantage, characterized by imports of technology and equipment, establishment of joint ventures, management, contracting, etc., consists of natural resources, labor, its geopolitical position and the size of its territory. In the world economic practice, countries with large reserves of natural resources, such as Saudi Arabia, Kuwait, have been able to provide a high level of per capita income. However, a number of other countries, particularly Africa, remain in poverty.

Thus, the availability of natural resources does not always ensure a competitive advantage for a country. It depends on how effectively you use them. Also, the competitive advantage based on factors of production is not considered stable, as the country's economy remains dependent on changes in world prices for raw materials, which is based on the fact that the development of resource-saving technologies has a major impact on them.

However, the countries that have gained a competitive advantage have formed OPECs, using their natural resources more efficiently. They are less dependent on changes in conjuncture because they control the world prices of resources themselves.

At the investment stage, the country's competitive advantage is determined by an active investment policy in which technologies and equipment are imported, and enterprises seek to acquire the best technologies, licenses, know-how. There will be further accumulation of capital. Most importantly, the competitive advantage provided by key factors is still important, but their impact is diminished. It should be noted that the investment phase does not provide a sustainable competitive advantage for the country, as 
bankruptcy can occur due to the wrong choice of priorities or technologies in a number of sectors.

Porter's theory of competitive advantage argues that investment-based competitiveness is likely to be maintained in high-capacity industries that provide savings at the expense of production volumes and do not require highly skilled labor and strong support sectors. In our opinion, this rule requires amendments, because the sectors in which investments are made do not have to be capital-intensive. For example, many food enterprises are not included in this category, but the development of this sector will stimulate demand in the domestic market. An increase in the volume of demand determines the supply, that is, an increase in the volume of production, which leads to an increase in capital investment. If the quality of domestic food products is competitive in foreign markets, the investment attractiveness of the food industry will be high.

At the stage of innovation, the country's competitive advantage is ensured by its own technologies, which make the economy more resilient to changes in world conditions and external influences.

The wealth stage is characterized by the fact that accumulated capital is a source of competitive advantage. However, M. Porter proved that a country that has become competitive at this stage may lose its competitive advantage (UK), the main reason for this is the decline in domestic competition. Firms become monopolists in an effort to consolidate their competitive advantage, and there is a merger of firms that cannot compete.

At the same time, at this stage, the country makes large foreign investments, but its goal is not to capture new sales markets, that is, the investment process becomes a form of capital sales. In turn, the country can return to the stages of its development. Thus the law of competition is manifested: moving forward requires constant improvement, and it is necessary to develop the advantages gained.

It should be noted that the country does not have to go through all stages of competitiveness, the development of competitive advantages can be in the form of leaps, in particular, Italy in the postwar period immediately moved from the factor stage to the innovation stage.

Our analysis of the scheme of the country's movement from one stage of competitiveness to another, proposed by M. Porter, as well as taking into account current trends in the world economy, allows us to distinguish the fifth stage of competitiveness. This is a stage of world leadership, which implies the country's monopoly power in the world market in the form of a competitive advantage. Just as any successful entrepreneur seeks to monopolize its local market, a wealthy country (especially the United States today) seeks to dominate the world market with an aggressive competitive strategy. And conversely, the lack of an aggressive competitive strategy when the wealth stage was reached led to the loss of the country's competitive advantage in the UK.

Thus, the development of the country's competitiveness should not end with the stage of gaining wealth, because there is a higher stage the stage of monopoly rule of the country.

In view of the above, we propose a supplemented scheme of the development of the country's competitiveness depending on the source of competitive advantage (Table 2).

\begin{tabular}{|c||c|c|c|l|l|}
\hline $\begin{array}{c}\text { Fact } \\
\text { or stage }\end{array}$ & $\begin{array}{c}\text { Investment } \\
\text { phase }\end{array}$ & $\begin{array}{c}\text { Innovati } \\
\text { on, innovation } \\
\text { phase }\end{array}$ & $\begin{array}{r}\text { We } \\
\text { alth stage }\end{array}$ & $\begin{array}{r}\text { The stage } \\
\text { leadership } \\
\text { (monopoly rule) in } \\
\text { the world }\end{array}$ \\
\hline
\end{tabular}


Stages of country competitiveness depending on the competitive advantage proposed by the author Of the developed countries, Switzerland and the United States have reached the stage of wealth, while Japan, Germany and Italy have approached this stage. The highest level of competitiveness achieved for developing countries is currently in the investment phase (China, Singapore). South Korea is entering a phase of innovation in terms of competitiveness.

According to the theory of competitive advantage, the situation in Uzbekistan is characterized by the fact that our country has a competitive advantage in terms of primary factors. Highly educated and skilled labor resources and a high level of scientific and technical development, as well as a favorable geopolitical situation in Central Asia demonstrate the strong competitive advantages of our republic. In turn, taking into account the potential of the country, which includes natural resources and enhances investment attractiveness, as well as the positive results of economic development (sustainable economic growth, increasing public confidence in the banking system), the country has the necessary conditions to enter the investment phase. in which the state plays an important role in realizing its potential.

The competitive advantage of any country stems from the competitive advantage of its industries. Their sources are determined, first of all, by the level of innovative developments. The experience of developed countries shows that the state, while actively implementing the function of general coordination of research in the country, provides information on innovative development trends in the world, as well as identifies areas for joint research with the private sector. At the same time, the main share of ITTKI costs, which is growing every year, falls on the private sector (in Japan, its share is $80 \%$ ).

The ability of a transition economy to finance $R \& D$ is not comparable to the scale of spending in developed countries. In this case, the main role of the state is to set priorities for scientific and technological development and ensure their financing, especially in the food industry.

Analysis of global trends in scientific and technological progress in food production allows us to express the goal of scientific supply of the food industry to ensure food security based on the production of food products that are harmless to human health, biologically complete and competitive. Achieving this goal implies the solution of the following tasks:

- Development of science-based criteria for safety and quality of agricultural raw materials and food products;

- Creation of food technologies that ensure the production of biologically complete agricultural products;

- Development of scientifically based ways and methods of obtaining plant and animal proteins from local raw materials and their rational use;

- Improving the system of quality standardization and certification and safety of agricultural raw materials and food products;

- the use of express methods of quality and safety control of food products, which is especially important in the context of small business development;

- reducing the cost of manual labor and increasing the level of mechanization and automation of technological processes;

- Creation of new technologies that provide deeper processing of local raw materials;

- Development of modern packaging technologies that ensure food safety and increase competitiveness;

- Development and introduction of advanced technologies for storage of raw materials and finished products;

- Expanding the range of local food products to meet the needs of all segments of the population, taking into account various factors, which necessitates the creation of the following new products:

1) Baby food products based on milk, grain, meat and fruits and vegetables, in particular, the 
country currently produces almost the entire range of specialized food products;

2) For treatment and prevention, including diabetic nutrition;

3) For the population living in ecologically unfavorable areas;

4) Having radioresistant properties, the ability to remove radio-nuclides and other harmful substances from the body;

5) Using national food traditions;

6) For different groups of the population with different levels of income.

In general, the main directions of research presented above should be adjusted in each sector of the food industry: meat, dairy, confectionery, fruits and vegetables, etc. it is the scientific supply of the food industry that creates a high level of sustainable competitive advantage and enhances the competitiveness potential of the industry.

It should be noted that the competitive advantages of firms, according to M. Porter's classification, are of two main types, which are conditioned by low costs or stratification of goods. Low costs characterize a firm's ability to design, manufacture, and sell goods at lower costs than competitors, which ensures real success because low production costs allow for affordable food prices for all categories of the population.

Product stratification is the process of creating product types that differ in their quality, service, advertising and marketing support, as well as for different segments of consumers. In turn, stratification provides the consumer with a valuable benefit in the form of a new type of product, a particular consumer feature of the service, which in this regard creates great opportunities in the production of food products. In this case, it applies to the creation of national food products, the use of local raw materials, production methods, certain types of packaging, the production of products for the prevention and treatment of various diseases, and so on. Currently, many segments of the market in Uzbekistan are not developed, and the existing market for local food products creates favorable conditions for entrepreneurs.

It should be noted that A.Yu. Yudanov, on the basis of the theory of biologist LG Ramensky, complements M. Porter's classification of competitive advantages with two more types, according to which the competitive advantages of firms are formed:

- Competitive advantages of the firm in relation to leaving competitors behind in the introduction of innovations;

- Competitive advantages associated with a high degree of flexibility, the ability to respond quickly to changes in market conditions.

In recent years, the concept of "intangible resources" has become especially important to describe the competitive advantages of enterprises, but in world practice has not yet developed a uniform interpretation of intangible resources. For example, in the work of ON Konstantinova there is a classification of intangible resources, according to which intangible resources are divided into intangible assets and competence. In this case, intangible assets include: trademarks, patents, copyrights, registered models, contracts and licenses, trade secrets, databases, product and enterprise reputation, organizational networks.

At the same time, competence is divided into functional and organizational cultures. Functional cultures embody the know-how of employees, suppliers, distributors, advertising agents, and other market participants, while organizational culture competencies tend to change, innovate management, teamwork, product quality, and service delivery. characterized by

Undoubtedly, intangible resources play an important role in shaping the competitive advantage of enterprises. In order to form and maintain competitive advantages, local food industry enterprises must implement the following principles, generalized to the theory of international competitiveness:

- the desire of the company's management for innovations, improvements and changes in all spheres of economic activity; 
- Improving and increasing the number of sources of competitive advantage;

- Apply a systematic approach to the formation of a competitive advantage that covers the entire process of creation, production and sale of products.

Issues of increasing competitiveness at all levels of the economy (state, industry, region, enterprise) require an approach based on a systemic approach to problem solving in relation to the formation of a competitive strategy.

Developed countries with market economies pay special attention to the competitiveness strategy, the United States has adopted a comprehensive law on trade and competitiveness, the EU has published the "EU White Paper", which reflects the regional strategy for building competitive advantage, measures to support national exporters in Japan actively used, France has adopted a plan with a special section on the development of exports.

World economic practice shows that in developed countries, state regulation provides a comprehensive approach to the implementation of reforms, the possible harmonization of all its directions and elements.

\section{References:}

[1] Bielski, S.; Romaneckas, K.; Novikova, A.; Šarauskis, E. Are higher input levels to triticale growing

technologies effective in biofuel production system? Sustainability 2019, 11, 5915. [CrossRef]

[2] Agnoletti, M.; Emanueli, F.; Corrieri, F.; Venturi, M.; Santoro, A. Monitoring Traditional Rural Landscapes.

The Case of Italy. Sustainability 2019, 11, 6107. [CrossRef]

[3] Ismayilov, V.I. Improving the Organizational-Economic Mechanisms of Production and Sale of Products in the Agricultural Sector. Ph.D. Thesis, Baku State University, Baku, Azerbaijan, 2017.
[4] Aliev, S.T. The Economy of Azerbaijan; Sumgait State University: Sumgait, Azerbaijan, 2018.

[5] 5. Natocheeva, N.; Borodin, A.; Rud, N.; Kutsuri, G.; Zholamanova, M.; Namitulina, A. Development of tools for realizing the potential of financial stability of enterprises. Entrep. Sustain. Issues 2019, 7, 1654-1665.

[6] Gulaliyev, M.G.; Abasova, S.T.; Samedova, E.R.; Hamidova, L.A.; Valiyeva, S.I.; Serttash, L.R. Assessment of agricultural sustainability (Azerbaijan case). Bulg. J. Agric. Sci. 2019, 25, 80-89.

[7] Parfitt, J.; Barthel, M.; Macnaughton, S. Food waste within food supply chains: Quantification and potential for change to 2050. Philos. Tran. R. Soc. B Biol. Sci. 2010, 365, 3065-3081. [CrossRef] [PubMed]

[8] Bai, C.; Sarkis, J. Green supplier development: Analytical evaluation using rough set theory. J. Clean. Prod.2010, 18, 1200-1210. [CrossRef]

[9] Dubey, J.P.; Calero-Bernal, R.; Rosenthal, B.M.; Speer, C.A.; Fayer, R. Sarcocystosis of Animals and Humans, 2nd ed.; CRC Press: Boca Raton, FL, USA, 2016.

[10] Ahi, P.; Searcy, C. A comparative literature analysis of definitions for green and sustainable supply chain management. J. Clean. Prod. 2013, 52, 329-341. [CrossRef]

[11] Fogarassy, C.; Nguyen, H.H.; Oláh, J.; Popp, J. Transition management applications to accelerate sustainable food consumption-comparative analysis between Switzerland and Hungary. J. Int. Stud. 2018, 11, 31-43.

[12] Popp, J.; Váradi, L.; Békefi, E.; Péteri, A.; Gyalog, G.; Lakner, Z.; Oláh, J. Evolution of integrated open aquaculture systems in Hungary: Results from a case study. Sustainability 2018, 10, 177. [CrossRef] 
[13] Dubey, $\quad$ R.; Gunasekaran, A.; Papadopoulos, T.; Childe, S.J.; Shibin, K.T.; Wamba, S.F. Sustainable supply chain management: Framework and further research directions. J. Clean. Prod. 2016, 142, 1119-1130. [CrossRef

[14] Seuring, S.; Müller, M. From a literature review to a conceptual framework for sustainable supply chain management. J. Clean. Prod. 2008, 16, 1699-1710. [CrossRef]

[15] Morali, O.; Searcy, C. A review of sustainable supply chain management practices in Canada. J. Bus. Ethics 2013, 117, 635-658. [CrossRef]

[16] Paulraj, A.; Chen, I.; Blome, C. Motives and performance outcomes of sustainable supply chain management practices: A multi-theoretical perspective. J. Bus. Ethics 2015, 145, 239-258. [CrossRef]

[17] Gulaliyev, M.G.; Muradov, R.S.; Hajiyeva, L.A.; Muradova, H.R.; Aghayeva, K.A.; Aliyev, E.S. Study

[18] of Human Capital Development, Economic Indicators and Environmental Quality. Ekoloji Dergisi 2019, 28, 495-503.

[19] Kirwan, J.; Maye, D.; Brunori, G. Reflexive governance, incorporating ethics and changing understandings of food chain performance. Sociol. Rural 2017, 57, 357377. [CrossRef]

[20] Abramova, T.S.; Kuskova, E.S.; Karpova, N.P. Ecological direction of logistics development. Probl. Econ. Manag. 2014, 6, 21-23.

[21] Kneafsey, M.; Venn, L.; Schmutz, U.; Balázs, B.; Trenchard, L.; Eyden-Wood, T.; Bos, E.; Sutton, G.; Blackett, M. Short Food Supply Chains and Local Food Systems in the EU. A State of Play of Their Socio-Economic Characteristics;
JRC Scientific and Policy Reports 2013;

Publications Office of the European Union: Luxembourg, 2013.

[22] Patzelt, H.; Shepherd, D.A. Recognizing opportunities for sustainable development. Entrep. Theory Pract. 2011, 35, 631-652. [CrossRef] 